\title{
MSMEs Understanding of Taxation During the COVID-19 Pandemic
}

\author{
Neneng Susanti ${ }^{1}$ \\ ${ }^{1}$ Faculty of Economics and Business \\ Universitas Widyatama, Bandung, Indonesia \\ neneng.susanti@widyatama.ac.id \\ Vincentia Wahju Widajatun ${ }^{2}$ \\ ${ }^{2}$ Faculty of Economics and Business \\ Universitas Widyatama, Bandung, Indonesia \\ Vincentia.wahju@widyatama.ac.id
}

(Received June 15, 2021, accepted July 19, 2021)

\begin{abstract}
This paper based on a community service activities held with the aim of providing an understanding of government policies in providing tax incentives; understanding of the period of payment, deposit and tax reporting; and calculation of PPh (income tax). The implementation of the community service was carried out using lecture, tutorial, and discussion methods. Activity material prepared regarding the introduction of taxes during pandemic in order to help MSMEs in dealing with the impact of COVID-19 with hope of providing understanding for MSMEs which can later be applied and transmitted to the wider community. The target of PKM counselling activities, those who participated, understood the material provided. Their understanding were quite good, it was seen from the questions asked and discussions quality of the participants. By understanding the material from this information dissemination activity, it is expected that MSMEs assisted by KADIN in the culinary and fashion sectors can do better planning in terms of financial strategies related to taxation policies during the pandemic.
\end{abstract}

Keywords: COVID-19; MSMEs; tax 


\section{Introduction}

Today economic landscape has changed dramatically. As shown in Figure 1, the Corona Virus global pandemic or often called COVID-19 pandemic and the current narrowing of economic activity has made the economy immobile, with a view that the pandemic is leading the economy into a prolonged and more severe recession that will occur (Muhyiddin \& Wardhana, 2020). The magnitude of world economic shocks is also uncertain, as is the case today. However, many fear that the decline in the global GDP level will continue to change. In fact, it might even be on the scale worse than the recession Indonesia has been through many years ago.

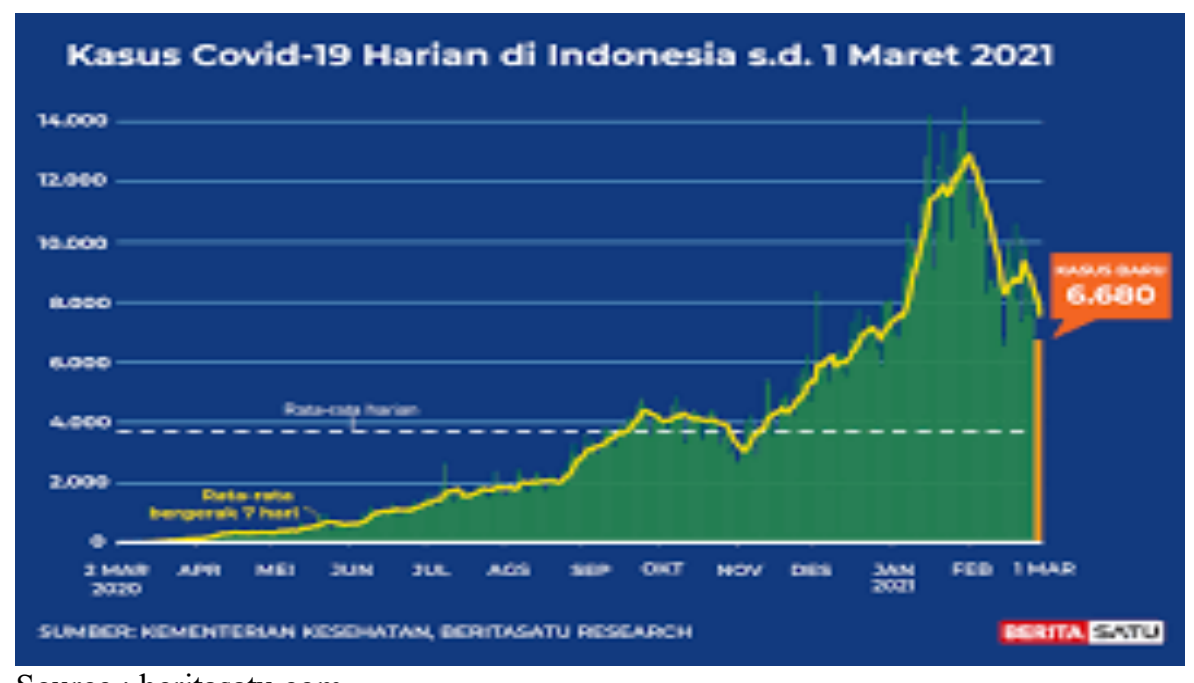

Source : beritasatu.com

Fig. 1. COVID-19 cases in Indonesia

Usaha Mikro, Kecil dan Menengah (MSMEs, term for micro, small and medium enterprises in Indonesia) is a business run by individuals, households, or small business entities. MSMEs are agents that can encourage continuous change in society because they can help to promote and to bring innovation and also increasing creativity (Dhewanto et al, 2015). In Indonesia, MSMEs have a strategic role and a great influence on the development of the national economy with a total number of enterprises of 64,194,057 in 2018 employing around 116,978,631 workers (Hardilawati, 2020).

The COVID-19 pandemic attack that occurred globally in almost all countries including Indonesia has had a negative impact on the economic sector, especially the MSMEs businesses. The negative impact due to the COVID-19 outbreak has hampered the wheels of the MSMEs business movement throughout Indonesia. Many MSMEs are forced to go out of business because they have to follow government regulations to carry out PSBB (Pembatasan Sosial 
Skala Besar, Large Scale Social Regulations), especially small businesses such as the culinary home industry.

The impact that occurred in Indonesia due to the COVID-19 pandemic was in almost all sectors, from employment to industrial performance in all sectors in the country. (Hadiwardoyo, 2020). During the implementation of avoiding the spread of COVID-19 by changing the work pattern and work culture of most businesses in Indonesia, a lot of work postponed and have impact on decreased work productivity (Mustajab et al., 2020). It is clear that the affected parties, namely the MSMEs, corporations and the financial sector as well as households are also affected (Antara, Pryanka, \& Candra, 2020). Due to the prolonged period of this pandemic, it has caused a decline in industrial performance in terms of processing and workmanship, starting from the production of goods, the demand for new products, as well as related to employment where many workers are laid off and subject to termination of employment (PHK, Pemutusan Hubungan Kerja in Indonesian). The most obvious difficulty faced by MSMEs is when MSMEs have to make installments of principal (debt) and interest to the banking institutions while sales activities decline and there is no income to pay credit obligations to the Bank, even forced to lay off employees or forced to terminate employment.

Before the COVID-19 pandemic, MSMEs had a strategic role in helping national economic growth. The contribution of MSMEs to Indonesia's GDP continues to increase to around $60 \%$, even from data in the MSMEs ministry it contributes 61.7 percent to Gross Domestic Product (GDP), or the equivalent of IDR 8,952 trillion from a total of IDR 14,837 trillion of Indonesia's GDP. Furthermore, the existence of MSMEs in the national economy reflects the important role of MSMEs in achieving the Sustainable Development Goals (SDGs) in Indonesia, because MSMEs can be at the forefront of achieving the SDGs economic pillar by creating and providing job opportunities, creativity and business innovation for inclusive and sustainable national economic growth in the face of globalization.

The MSMEs assisted by the West Java Kadin began to shift from 2017. The fashion and culinary business sector are the sectors with the largest number of MSMEs (52\%), while the rest are the sectors of handicrafts, cooking spices, cosmetics, husbandry, fragrances, herbal drinks, and health equipment. 
While MSMEs in Indonesia are developing, the Corona Virus or virus known as COVID-19 has caused chaos in the economic field. Not only big industries, the Corona virus pandemic has also troubled MSMEs players in Indonesia. Especially recently, a study shows that COVID-19 will reduce the percentage of Indonesia's economic growth in 2020 by $0.1 \%$. Broadly speaking, the real impact of COVID-19 pandemic on the MSMEs sector in Indonesia is to the buying and selling activities in Indonesia. Raw materials are difficult to obtain, distribution is hampered, and service providers are also affected by COVID-19 pandemic. The income of the MSMEs has decreased by about 50\%. The COVID-19 pandemic has a very significant impact on the domestic economy of the nation-state and the existence of MSMEs.

Kuncoro in (Setyanto, 2015) explains more specifically the factors that hinder business development, first is the difficulty in obtaining market opportunities and expanding market share. Second, due to limited sources of sufficient funds, funds are difficult to obtain. Third, lack of understanding in the field of organization and human resource management. Fourth, the lack of business partners. Fifth, unfair competition between entrepreneurs. Sixth, the coaching and training carried out have not been integrated, as well as the lack of public awareness and trust in the existence of small businesses.

The COVID-19 pandemic has caused an economic shock, which affects the economy of individuals, families, micro, small, medium and large companies, and even the country's economy. Its coverage includes local, national and even global (Taufik, Ayuningtyas \& Kusumah, 2020).

One of the efforts provided by the government in reducing the spread of COVID-19 virus is through social distancing. Social distancing is an effort to break the chain of transmission of COVID-19 virus, thereby reducing the productivity of economic activities and business entities, which leads to lower taxes. In addition, COVID-19 pandemic weakens the rupiah exchange rate and reduces people's purchasing power. In response to this, the government took a strategy to maintain business in various industries affected by COVID-19 pandemic by providing economic stimulus in the form of tax incentives. Previously, the government had established a preferential tax policy through regulation number PMK-23/PMK.03/2020, but the regulation did not cover all affected industries. As a result of the spread of COVID-19 virus, more and more business sectors, including small and medium enterprises, have to bear the financial burden. 
The COVID-19 pandemic that is still endemic results in resilience the national economy underwent significant evaluation and deregulation. One of the pillars of national economic resilience is in the revenue sector tax. The rapidly growing and dynamic role of society must be utilized, namely in the context of improving legal development and resilience national economy. The dynamics of the community's role including as a payer taxes, an important role as a form of participation in national development.

Compliance with various tax obligations is a problem that is often faced by many Micro, Small and Medium Enterprises (MSMEs). Many MSME actors do not know that they are already included in the criteria for certain entrepreneurs with a turnover of below Rp 4.8 billion per year or some even above Rp 4.8 billion per year. Some of them do not know that they have fulfilled the requirements to have a NPWP, do not know if they have to report an SPT, and what is more, their understanding of various other rules and policies related to MSME taxation (Sandra et al., 2019). With this condition, it means that there is a need for ongoing assistance to MSMEs so that MSME actors understand the ins and outs of taxation so that they can see the convenience and various tax facilities that support their business activities. Cooperation is needed between the government, in this case the Directorate General of Taxes (DGT), with many parties, so that the socialization activities for MSME actors can be carried out properly, considering the large number of MSMEs in Indonesia. So far, DGT has collaborated with universities through the establishment of a Tax Center, one of which is to help socialize various government policies, especially taxes, to various parties, including SMEs. Universities also carry out many community service activities related to taxation. (Arvita \& Tjiptohadi Sawarjuwono, 2020)

According to data from the Ministry of Cooperatives and SMEs (www.kemenkop.go.id), in Semester 1 of 2019 the number of micro businesses was $63,350,222$ (98.68\% of the total number of businesses in Indonesia), small businesses were 783,132 (1.22 \%) and medium enterprises as much as $6.702(0.09 \%)$. So it can be said that almost $99.9 \%$ of the number of businesses in Indonesia are dominated by MSMEs, and the remaining $0.01 \%$ are large businesses. MSMEs need ongoing assistance in order to survive and thrive. Assistance to MSMEs which is the task of the Ministry of Cooperatives and SMEs is also widely carried out by government agencies, BUMN/BUMD, private and non-governmental organizations (NGOs), as well as universities. Many things are provided in this assistance, starting from how 
to market products, get credit, manage consumers, package products to make them attractive, create advertising materials, accounting, and taxation.

Apart from taxation policies, the government has also issued several policies that pay attention to the liquidity of the MSMEs, provided debt relief or credit instalments for MSMEs, One of the policies provided is a tax incentive not to pay $0.5 \%$ Final PPh for MSMEs whose turnover does not exceed IDR 4.8 billion per year, and even postponed the payment process for the next six months. This includes administrative procedures to facilitate obtaining a loan for emergency situations.

Tax decreases as tax expenditures increase. An increase in tax spending will increase government spending which will provide a multiplier effect for the national economy, including increased public purchasing power (this will increase the value added tax) and economic stability, corporate productivity and good cash management (expected to increase). End of incentive period is potential to handle income tax later (Harahap et al., 2018).

\section{Method}

Method of delivering the community service began by conducting field observations and coordination with partners. The initial survey was conducted by the proposing team to find out the problems faced by partners regarding the impact of COVID-19 pandemic.

The method of implementing activities in this community service program was in the form of providing assistance through webinars for the target audiences, namely MSME entrepreneurs in the city of Bandung, West Java Province. Assistance in the form of training and information sharing was carried out informally, in a two-way format and involves the participation of the MSME entrepreneurs to direct questions and answers, as well as to discuss the problems they face. Experts were involved as speakers, who presented materials and guided the discussion process and also a simulation process for the preparation of planning to map the needs of MSME entrepreneurs who interested to apply better taxation management.

After the training was carried out, it was necessary to have an approach method. The target participants then were involved in the process of drafting an application pattern as an output of their understanding about the taxation management, which would also support economic added value and their creativity in communicating with their customers. The implementation pattern 
was an approach made by the implementation team for community service programs for target audiences, in order to achieve targets effectively and efficiently.

The implementation of community service was carried out online on February 25, 2021 via Google Meet application as shown in Figure 2. The method of community service activities used were the lecture, tutorial, and discussion method chosen to convey the material. The use of laptops and Liquid Crystal Display (LCD) helped the trainees to understand and remember the relatively large number of training materials in such a limited training time. Evaluation of the implementation of this community service program was carried out in the form of distributing questionnaires to the MSME entrepreneurs involved, to perceive their change in understanding and their ability to manage their tax requirements.

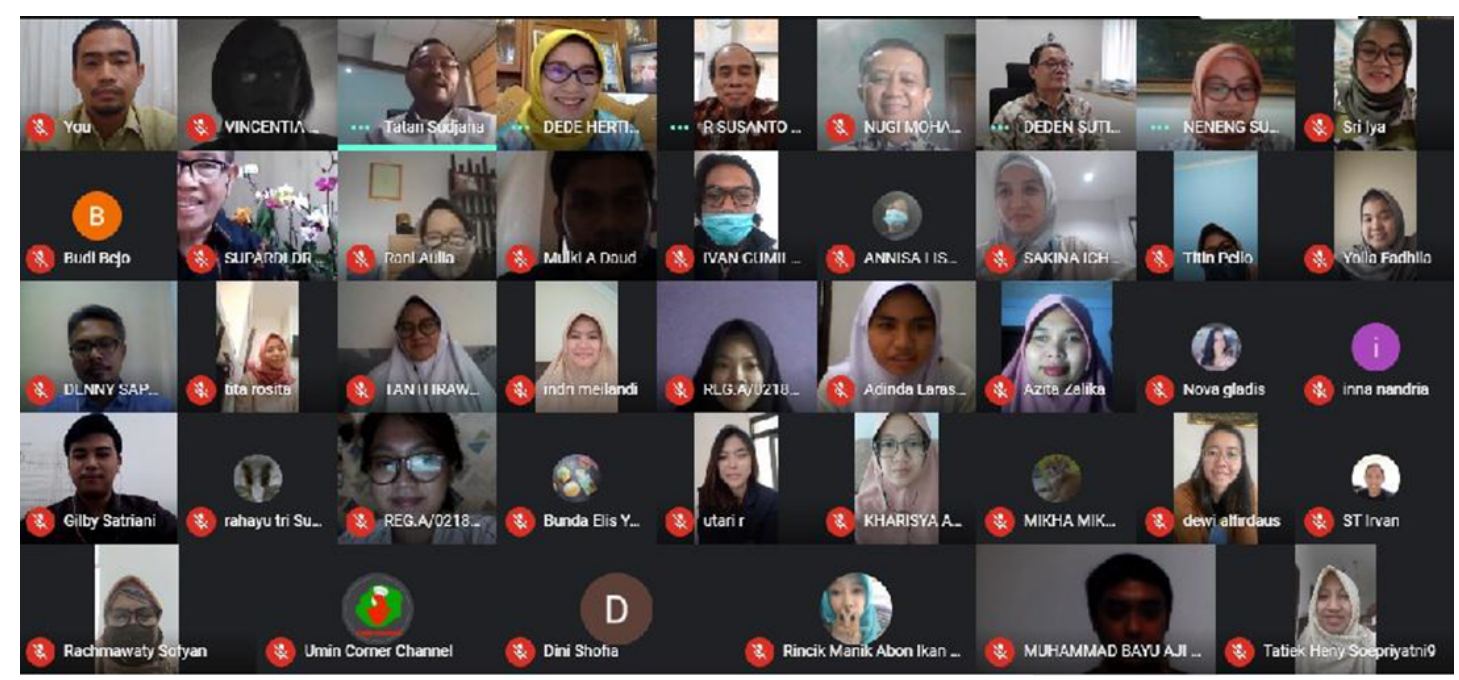

Fig. 2. Community service through Google Meet application

\section{Results and Discussions}

Based on information obtained from the Ministry of Cooperatives and Small and Medium Enterprise of the Republic of Indonesia, generally, MSMEs have experienced rapid development and growth over the years. For example, in 2010, the total number of MSMEs units was 52,769,426. Then the number has reached 63 million in the latest news.

MSMEs have a very large and crucial contribution to our economy at a macro level. The Indonesian Ministry of Cooperatives and Small and Medium Enterprise reports that in terms of number of units, MSMEs have a share of around 99.99\% (62.9 million units) of the total business entities in Indonesia (2017), while large businesses are only $0.01 \%$ or around 5,400 
units. Micro enterprises absorb around 107.2 million workers (89.2\%), small enterprises 5.7 million (4.74\%), and medium enterprises 3.73 million (3.11\%); while big enterprises absorb around 3.58 million people. This means that collectively, MSMEs absorb around $97 \%$ of the national workforce, while large enterprises only absorb about $3 \%$ of the total national workforce.

Since the COVID-19 pandemic was declared, many areas of the domestic and global economy have been affected. The pandemic has had the most significant impact on the micro, small and medium enterprises sector. When the COVID-19 outbreak was rampant in Indonesia, various sources reported that MSMEs entrepreneurs began to face various business difficulties, so that the income of MSMEs fell by at least around 50\%. Therefore, the government has taken a strategy to maintain business in various industries which affected by COVID-19 pandemic by providing economic stimulus in the form of tax incentives. (Faisal \& Nirmala, 2020)

Taxes are the largest main source of national financing in Indonesia, accounting for $80 \%$. With such a large proportion, unfortunately most MSMEs entrepreneurs still do not know the tax system or have never fulfilled their tax obligations. Entities of small, micro and medium enterprises with a turnover of up to IDR 4.8 billion are subject to a $0.5 \%$ tariff which has been in effect since July 2018. Rates have been lowered from the previous $1 \%$.

This change in MSMEs tax rates is contained in Government Regulation (Peraturan Pemerintah, PP) Number 23 of 2018 concerning Income Tax on Business Revenue or Obtained by Taxpayers with Certain Gross Circulation. This Government Regulation replaces the previous regulation, namely PP Number 46 of 2013. The aim of reducing the tax rate by the government is to help small and medium enterprises develop their businesses and maintain cash flow so that it can be used as supplementary capital. Thus, there is no longer any reason for MSME entrepreneurs not to fulfil their tax obligations. To fulfil their tax obligations, MSMEs must have an NPWP first (Nomor Pokok Wajib Pajak, tax ID number). However, many MSME entrepreneurs consider NPWP registration difficult and time-consuming, so they prefer not to fulfil their tax obligations rather than going back and forth at the tax office waiting for registration. In fact, if the necessary requirements have been completed properly and the identity of the registrant is clear, the NPWP registration process will not take long.

The problem that often arises at TPT counters (tax payment and administration offices) is that sometimes taxpayers register their NPWP only to meet bank requirements or as a condition for 
issuing business licenses. In this way, the necessary requirements cannot be properly met. Because taxpayers have to fill out forms at the counters first and have to fill out forms at the counters so that they can be processed immediately, this activity can hamper or prolong the NPWP registration process.

Requirements for NPWP (for entrepreneur) registration include photocopies of ID cards, photocopies of business certificates or SKUs (also known as Surat Keterangan Usaha in Indonesian) related to business licenses, and photocopies of family certificates (mandatory if the registrant is a wife), signed with a stamp of IDR 6000, and filling out the NPWP registration form provided by the tax bureau and signed by the applicant.

If all requirements and documents are complete, NPWP registration does not have to wait long. In addition to going directly to the tax bureau, applicants can also fill in their personal data on the online page via https://ereg.pajak.go.id to complete the NPWP registration. But for a complete NPWP registration it is recommended to go directly to the Departemen Pendapatan Pedalaman. When the NPWP registration has been completed, the obligations must be fulfilled by business taxpayers are making the actual periodic tax payments and reporting. Payments are made every month by taking into account the revenue earned in the particular month. Then the revenue is multiplied by the $0.5 \%$ tax rate for the revenue obtained from that month.

The revenue doesn't have to be the same every month, because for entrepreneurs, the monthly income will inevitably go up or down. Regarding each taxation period, tax payment is no later than the 15th of the following month, for example for tax period of August, the maximum payment amount is due in September 15. Payment can be made via ATM or mobile banking (but there are still many banks that have conventional transaction method via bank tellers, actually available at almost all Indonesian bank institutions), and post offices. Bank payments can also be made through the electronic marketplace application. These various ways to make tax payment make it easier for taxpayers to settle their obligation every month.

When tax payment is complete, then the final step is to report the annual tax return. Annual SPT reports (Surat Pemberitahuan Tahunan in Indonesian) can be completed at KPP (Kantor Pelayanan Pajak in Indonesian, tax administration office) or through the online website pajak.go.id. The deadline for submitting SPT for particular year is from January to March of the following year. For example, if a person wants to report an annual tax return for the 2019 
tax year, he/she can submit the report from January 2020 to March 2020. With technological advances that make it more convenient for taxpayers, it is expected that MSMEs entrepreneurs in Indonesia, can fulfil their tax obligations in an orderly manner.

\section{Conclusion}

The development of MSMEs in West Java and Indonesia shows a good trend. The support provided by the government has a positive impact on the growth rate of micro, small and medium enterprises in many ways. Utilization of technology and communication facilities, channelling bank loans to the public, and factors that encourage the development of small and micro enterprises in Indonesia (among others, are the reduction in the final income tax rates and factors determined by the Indonesian government in the field of taxation), government policies (tax incentives) are forms of actions from the government to assist small and medium enterprises in their daily activities. Even so, because of several supporting factors those have not been effective, the growth is still relatively slow.

Small, medium and micro enterprises have played an important role in maintaining the national economy. The sector contributes more than $60 \%$ of GDP (Gross Domestic Product) and reduces unemployment by contributing more than $95 \%$ of the workforce, however the COVID19 pandemic has reduced its business activities, so there are needs to support the MSMEs to make sure their survival. Due to economic pressure caused by the COVID-19 pandemic, the government through the supervision of the Minister of Finance has provided tax incentives for taxpayers affected by COVID-19.

\section{Acknowledgements}

We would like to express our gratitude to all parties, especially Widyatama University and LP2M, who have provided funding for this community service program in accordance with the "Community Service Implementation Contract" (documented in contract number. 051/SPC2/LP2MUTAMA/V/2020) signed on January $11^{\text {th }}, 2021$ so that these community service activities can be carried out and run smoothly. 


\section{References}

Antara, Pryanka, A., \& Candra, S. A. (2020, June 11). Empat Sektor Ekonomi yang Paling Tertekan Pandemi Covid-19. Republika.Co.Id, p. https://republika.co.id/berita/q831lp409/empat-sek.

Arvita, R., \& Tjiptohadi Sawarjuwono. (2020). Etika Profesional Konsultan Pajak Dalam Melaksanakan Perannya Sebagai Mitra Wajib Pajak Dan Pemerintah. E-JURNAL AKUNTANSI, 1, 88-100.

Dhewanto, W., Indradewa, R., Ulfa, W. N., Rahmawati, S., Yoshanti, G., \& Lumanga, C. Z. (2015). Manajemen Inovasi untuk Usaha Kecil dan Mikro. Bandung: ALFABETA.

Faisal, M., \& Nirmala, M. P. (2020). COVID-19 and Economic Policy Options: What Should the Government do? Jurnal Inovasi Ekonomi, 5(02), 45-52. https://doi.org/10.22219/jiko.v5i3.11834

Hadiwardoyo, W. (2020). Kerugian Ekonomi Nasional Akibat Pandemi Covid-19. Baskara: Journal of Business and Entrepreneurship, 2(2), 83-92. https://doi.org/10.24853/baskara.2.2.83-92

Harahap, M., Sinaga, B. M., Manurung, A. H., \& Maulana, T. N. A. (2018). Dampak Kebijakan Dan Makroekonomi Terhadap Efektivitas Penerimaan Pajak Di Bursa Efek Indonesia. Mix: Jurnal Ilmiah Manajemen, 8(2), 400. https://doi.org/10.22441/mix.2018.v8i2.013

Hardilawati, W. laura. (2020). Strategi Bertahan UMKM di Tengah Pandemi Covid-19. Jurnal Akuntansi Dan Ekonomika, 10(1), 89-98. https://doi.org/10.37859/jae.v10i1.1934

Muhyiddin, \& Wardhana, D. (2020). Covid-19 Outbreak and Development Planning in Indonesia. The Indonesian Journal of Development Planning, IV(1). https://doi.org/10.1177/000944559803400206

Mustajab, D., Bauw, A., Rasyid, A., Irawan, A., Akbar, M. A., \& Hamid, M. A. (2020). Working From Home Phenomenon As an Effort to Prevent COVID-19 Attacks and Its Impacts on Work Productivity. TIJAB (The International Journal of Applied Business), 4(1), 13. https://doi.org/10.20473/tijab.v4.i1.2020.13-21

Sandra, A., Hanif, H., Arfianti, R. I., \& Apriwenni, P. (2019). Pendampingan Pajak UMKM: Masalah dan Solusinya. ACADEMICS IN ACTION Journal of Community Empowerment, 1(1), 1. https://doi.org/10.33021/aia.v1i1.737

Taufik, Ayuningtyas, \& Kusumah, J. R. (2020). The Impact of Covid-19 Pandemic on Business and Online Platform Existance. Jurnal Ilmu Manajemen Terapan (JIMT), 22(5), 21-32. 
Kementerian Keuangan. 2020. PMK-23/PMK.03/2020.

https://www.kemenkeu.go.id/media/14768/pmk-23-tahun-2020pdf.pdf www.kemenkop.go.id, accessed on March 6, 2021.

http://www.depkop.go.id/data-umkm, accessed on March 6, 2021.

https://www.ukmindonesia.id/baca-artikel/62, accessed on March 6, 2021. 